Sholichah, et al/Jurnal Ekonomi Syarieh Teori dan Terapan Vol. 6 No. 2 Februari 2019: 228-242; ANALISA CAPITAL ADEQUACY RATIO (CAR), RETURN ON ASSET (ROA), NON-PERFORMING FINANCING (NPF), DAN FINANCING TO DEPOSIT RATIO (FDR) BANK PANIN DUBAI SYARIAH SEBELUM DAN SESUDAH IPO PERIODE 2011-2017

\title{
ANALISA CAPITAL ADEQUACY RATIO (CAR), RETURN ON ASSET (ROA), NON-PERFORMING FINANCING (NPF), DAN FINANCING TO DEPOSIT RATIO (FDR) BANK PANIN DUBAI SYARIAH SEBELUM DAN SESUDAH IPO PERIODE 2011-2017
}

\author{
Dhevy Ulinnuha Sholichah \\ Departemen Ekonomi Syariah-Fakultas Ekonomi dan Bisnis-Universitas Airlangga \\ Email : dhevyulinnuha1@gmail.com
}

Dian Filianti

Departemen Ekonomi Syariah- Fakultas Ekonomi dan Bisnis-Universitas Airlangga Email : dian.filianti@gmail.com

\begin{abstract}
:
This research analyzed the difference between sharia bank's financial performance before and after Initial Public Offering (IPO) for a period of 2011-2017. Sharia commercial bank that meets the criteria is Panin Dubai Syariah Bank. Data used in this research is secondary data collected from the bank's annual financial statements. Financial ratios used as variables in this research are Capital Adequacy Ratio (CAR), Non-Performing Financing (NPF), Return On Assets (ROA), and Financing to Deposit Ratio (FDR). The results that tested using Paired T-Test and Wilcoxon Signed Rank Test show that CAR, NPF, ROA, and FDR on Panin Dubai Syariah Bank indicate there is a significant difference between before and after IPO. The significant differences indicated using significance levels of $1 \%, 5 \%$, and $10 \%$.

Keywords: Sharia Bank, Financial Performance, CAR, NPF, ROA, FDR, Initial Public Offering
\end{abstract}

\section{PENDAHULUAN}

Globalisasi tidak hanya berpengaruh dalam bidang teknologi dan informasi saja, namun juga dalam bidang ekonomi. Hal ini ditandai dengan meningkatnya minat masyarakat terhadap investasi. Saat ini, berbagai macam sarana untuk berinvestasi telah tersedia, salah satunya adalah investasi di pasar modal. Pasar modal berfungsi sebagai lembaga perantara yang mempertemukan antara pihak yang memiliki kelebihan dana (investor) dengan pihak yang membutuhkan dana (emiten). Bagi perusahaan, mendapatkan harta dengan cara yang halal merupakan sebuah keharusan. Allah SWT berfirman dalam Al-Qur'an Surat An-Nisa' ayat 29:

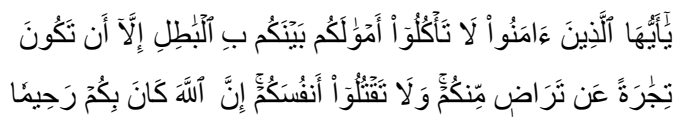

Artinya: "Hai orang-orang yang beriman, janganlah kamu saling memakan harta sesamamu dengan cara yang batil, kecuali dengan jalan perniagaan yang berlaku dengan suka sama-suka di antara kamu. Dan janganlah kamu membunuh dirimu; sesungguhnya Allah adalah Maha Penyayang kepadamu". (QS 4:29, Departemen Agama RI, 2018).

Salah satu sarana yang dapat digunakan perusahaan untuk memperoleh tambahan modal adalah

1) Jurnal ini merupakan bagian dari skripsi Dhevy Ulinnuha, NIM: 041411431098, yang diuji pada tanggal 18 Juli 2018 
Sholichah, et al/Jurnal Ekonomi Syarieh Teori dan Terapan Vol. 6 No. 2 Februari 2019: 228-242;

ANALISA CAPITAL ADEQUACY RATIO (CAR), RETURN ON ASSET (ROA), NON-PERFORMING FINANCING (NPF), DAN FINANCING TO DEPOSIT RATIO (FDR) BANK PANIN DUBAI SYARIAH SEBELUM DAN SESUDAH IPO PERIODE 2011-2017

dengan menjual saham di pasar modal. Proses penjualan saham untuk pertama kalinya kepada investor publik atau masyarakat luas disebut penawaran umum perdana atau lebih dikenal dengan istilah Initial Public Offering (IPO) (Tandelilin, 2010:74). Bursa Efek Indonesia (BEI) menjelaskan bahwa salah satu manfaat yyang akan diperoleh perusahaan ketika menjadi perusahaan publik adalah terbukanya akses perusahaan terhadap sarana pendanaan jangka panjang sehingga nilai ekuitas perusahaan akan meningkat dan perusahaan memiliki struktur modal yg optimal. Tambahan modal yang diperoleh dari menjual saham perdana ke publik kemudian dapat digunakan oleh perusahaan untuk melakukan ekspansi yang akan meningkatkan performa dan kinerja perusahaan di masa yang akan datang.

Hingga saat ini, bank syariah yang telah berhasil melakukan IPO adalah PT Bank Panin Dubai Syariah, Tbk. Bank tersebut resmi menjadi bank syariah pertama yang berhasil go public dan mencatatkan sahamnya di Bursa Efek Indonesia (BEI) pada tanggal 15 Januari 2014. Meskipun Bank Panin Dubai Syariah termasuk sebagai Bank Umum Syariah yang baru saja beroperasi, namun Bank Panin Dubai Syariah berhasil mengungguli mitranya dan mencatatkan sahamnya di BEl. Ada beberapa cara yang dapat digunakan untuk mengukur kinerja keuangan perusahaan, salah satunya adalah dengan menggunakan analisis rasio keuangan. Umam (2013:341) dalam bukunya menyatakan bahwa analisis rasio keuangan digunakan untuk membandingkan rasio saat ini dengan rasio masa lalu, dan masa yang akan datang dalam perusahaan yang sama untuk mempelajari ada atau tidaknya perubahan serta menentukan apakah terdapat perbaikan atau penurunan dalam kondisi keuangan dan kinerja perusahaan. Di samping itu, penilaian kinerja bank menggunakan rasio di atas sesuai dengan pendapat Muljono (1999) dalam Hutagalung et. al (2013) bahwa perbandingan dalam bentuk rasio menghasilkan angka yang lebih objektif karena pengukuran kinerja tersebut lebih dapat dibandingkan dengan bank-bank yang lain ataupun dengan periode sebelumnya.

Berdasarkan latar belakang yang telah dipaparkan diatas, maka dapat diambil rumusan masalah pada penelitian ini, yaitu apakah terdapat perbedaan CAR, NPF, ROA, dan FDR pada Bank Panin Dubai Syariah sebelum dan sesudah Initial Public Offering (IPO) periode 2011-2017? 
Sholichah, et al/Jurnal Ekonomi Syarieh Teori dan Terapan Vol. 6 No. 2 Februari 2019: 228-242;

ANALISA CAPITAL ADEQUACY RATIO (CAR), RETURN ON ASSET (ROA), NON-PERFORMING FINANCING (NPF), DAN FINANCING TO DEPOSIT RATIO (FDR) BANK PANIN DUBAI SYARIAH SEBELUM DAN SESUDAH IPO PERIODE 2011-2017

Adapun tujuan penelitian ini adalah untuk mengetahui ada atau tidaknya perbedaan CAR, NPF, ROA, dan FDR pada Bank Panin Dubai Syariah sebelum dan sesudah Initial Public Offering (IPO) periode 2011$2017 ?$

\section{LANDASAN TEORI}

Tandelilin (2010:74) dalam bukunya mendefinisikan Initial Public Offering (IPO) sebagai proses penjualan saham untuk pertama kalinya kepada investor publik atau masyarakat luas. Undang-undang No. 8 Tahun 1995 tentang Pasar Modal mendefinisikan Initial Public Offering atau penawaran umum sebagai kegiatan penawaran Efek yang dilakukan oleh Emiten untuk menjual Efek kepada masyarakat berdasarkan tata cara yang diatur dalam Undangundang ini dan peraturan pelaksanaannya.

Setiap perusahaan yang telah melakukan go public, baik bank maupun non bank wajib melaporkan kegiatan usahanya dalam suatu waktu (periode tertentu). Informasi yang berkaitan dengan perusahaan seperti posisi keuangan, kinerja serta perubahan posisi keuangan aktivitas operasional perusahaan diperoleh dari laporan keuangan perusahaan. Umam (2013:332) mendefinisikan laporan kevangan sebagai ringkasan dari suatu proses pencatatan, serta ringkasan dari transaksi keuangan yang disusun dengan maksud untuk menyediakan informasi keuangan mengenai perusahaan kepada pihakpihak yang berkepentingan sebagai bahan pertimbangan dalam pengambilan keputusan.

Dengan adanya laporan kevangan, maka pihak manajemen perusahaan dapat melakukan pengambilan keputusan untuk meningkatkan kinerja perusahaan di masa yang akan datang. Sedangkan bagi investor, laporan keuangan digunakan untuk memprediksi masa depan sebelum melakukan investasi dan menanamkan modalnya di perusahaan.

Menurut Muhamad (2015:242), gambaran kinerja suatu bank pada umumnya dan bank syariah pada khususnya, biasanya tercermin dalam laporan keuangannya. Untuk dapat membaca dan mengartikan laporan keuangan, maka diperlukan adanya analisis terhadap laporan keuangan.

Salah satu teknik analisis laporan kevangan yang paling banyak digunakan saat ini yaitu analisis rasio keuangan. Menurut Umam (2013:341), analisis rasio keuangan digunakan untuk membandingkan rasio saat ini dengan masa lalu, dan masa yang akan datang dalam perusahaan yang sama untuk mempelajari komposisi perubahan dan menentukan apakah 
Sholichah, et al/Jurnal Ekonomi Syarieh Teori dan Terapan Vol. 6 No. 2 Februari 2019: 228-242;

ANALISA CAPITAL ADEQUACY RATIO (CAR), RETURN ON ASSET (ROA), NON-PERFORMING FINANCING (NPF), DAN FINANCING TO DEPOSIT RATIO (FDR) BANK PANIN DUBAI SYARIAH SEBELUM DAN SESUDAH IPO PERIODE 2011-2017

terdapat perbaikan atau penurunan kondisi keuangan perusahaan.

Dalam penelitian ini, analisis rasio yang digunakan, antara lain: rasio permodalan, rasio Kualitas Aktiva Produktif (KAP), rasio rentabilitas, dan rasio likuiditas.

Rasio yang terkait dengan permodalan dalam perbankan adalah Capital Adequacy Ratio (CAR). Seperti yang telah dijelaskan sebelumnya oleh BEl bahwa salah satu manfaat yang akan diperoleh perusahaan ketika menjadi perusahaan publik adalah terbukanya akses perusahaan terhadap sarana pendanaan jangka panjang sehingga nilai ekuitas perusahaan akan meningkat dan perusahaan memiliki struktur modal yg optimal. Dengan adanya tambahan modal yang diperoleh bank melalui penjualan saham kepada publik, maka diharapkan rasio CAR yang dimiliki oleh bank juga mengalami peningkatan.

Rasio Kualitas Aktiva Produktif (KAP) pada bank syariah diukur dengan menggunakan Non Performing Finance (NPF). Dengan adanya keputusan menjadi perusahaan publik, maka bank akan memperoleh tambahan modal melalui penjualan saham di bursa. Tambahan modal tersebut diharapkan dapat digunakan oleh bank untuk melakukan ekspansi dalam menyalurkan pembiayaan sehingga nilai NPF akan mengalami penurunan. Penurunan ini terjadi dikarenakan dengan adanya tambahan modal, maka faktor pembagi dalam NPF semakin besar sehingga terjadi penurunan nilai NPF.

Dalam industri perbankan, rasio rentabilitas yang biasa digunakan adalah Return on Asset (ROA). Seperti yang telah dijelaskan sebelumnya oleh BEl bahwa salah satu manfaat yang akan diperoleh perusahaan ketika menjadi perusahaan publik adalah terbukanya akses perusahaan terhadap sarana pendanaan jangka panjang. Jika modal yang dimiliki oleh perusahaan bertambah, maka diharapkan nilai aktiva yang dimiliki perusahaan juga semakin meningkat sehingga dapat menghasilkan laba yang optimal bagi perusahaan.

Rasio

likuiditas menggambarkan kemampuan bank dalam memenuhi kewajiban hutangnya dan kewajiban lain serta memenuhi permintaan kredit yang diajukan tanpa terjadi penangguhan. Pada bank syariah, rasio ini diukur dengan menggunakan Financing to Deposit Ratio (FDR). Dengan adanya keputusan go public, maka bank akan memperoleh tambahan modal melalui penjualan saham di bursa. Tambahan modal tersebut diharapkan dapat digunakan oleh bank untuk mempertahankan kondisi likuiditas 
Sholichah, et al/Jurnal Ekonomi Syarieh Teori dan Terapan Vol. 6 No. 2 Februari 2019: 228-242;

ANALISA CAPITAL ADEQUACY RATIO (CAR), RETURN ON ASSET (ROA), NON-PERFORMING FINANCING (NPF), DAN FINANCING TO DEPOSIT RATIO (FDR) BANK PANIN DUBAI SYARIAH SEBELUM DAN SESUDAH IPO PERIODE 2011-2017

bank sesuai batas yang telah ditentukan oleh Bank Indonesia.

\section{METODE PENELITIAN}

Penelitian ini menggunakan pendekatan kuantitatif. Variabel variabel yang digunakan dalam penelitian ini adalah:

1. Capital Addequacy Ratio (CAR)

2. Non Performing Financing (NPF)

3. Return On Asset (ROA)

4. Financing to Deposit Ratio (FDR)

\section{Definisi Operasional}

Definisi operasional dari variabel yang digunakan dalam penelitian ini adalah sebagai berikut:

1. Capital Addequacy Ratio (CAR) CAR adalah rasio kinerja bank untuk mengukur kecukupan modal yang dimiliki bank untuk menunjang aktiva yang mengandung atau menghasilkan risiko, serta sebagai indikator terahadap kemampuan bank untuk menutupi penurunan aktivanya sebagai akibat dari kerugian bank-bank yang disebabkan oleh aktiva-aktiva yang beresiko (Dendawijaya, 2005:121)

$$
\text { CAR }=\frac{\text { Modal }}{\text { ATMR }} \times 100 \%
$$

2. Non Performing Financing (NPF) NPF adalah perbandingan antara pembiayaan bermasalah dengan total pembiayaan.
Pembiayaan Bermasalah

$$
\begin{aligned}
& \text { NPF }=\longrightarrow \text { X 100\% } \\
& \text { Total Pembiayaan }
\end{aligned}
$$

3. Return On Asset (ROA)

ROA merupakan rasio yang menggambarkan kemampuan bank dalam mengelola dana yang diinvestasikan dalam keseluruhan aktiva yang menghasilkan keuntungan (Muhamad, 2015: 254).

$$
\mathrm{ROA}=\frac{\text { Laba Sebelum Pajak }}{\text { Rata-rata Total Aset }} \times 100 \%
$$

4. Financing to Deposit Ratio (FDR)

FDR yaitu rasio kredit yang diberikan kepada pihak ketiga dalam rupiah dan valuta asing, tidak termasuk kredit kepada bank lain, terhadap dana pihak ketiga yang mencakup giro, tabungan, dan deposito dalam rupiah dan valuta asing, tidak termasuk dana antarbank (IBI, 2014:287).

$$
\text { FDR }=\frac{\text { Pembiayaan }}{\text { Dana Pihak Ketiga }} \times 100 \%
$$

\section{Jenis dan Sumber Data}

Dalam penelitian ini, jenis dan sumber data diperoleh dari laporan keuangan publikasi tahunan yang diterbitkan secara online melalui website resmi Bank Indonesia dan Bank Panin Dubai Syariah selama kurun waktu 3 tahun sebelum IPO yaitu periode 2011 hingga 2013 dan 3 tahun sesudah IPO yaitu periode2015 hingga 
Sholichah, et al/Jurnal Ekonomi Syarieh Teori dan Terapan Vol. 6 No. 2 Februari 2019: 228-242; ANALISA CAPITAL ADEQUACY RATIO (CAR), RETURN ON ASSET (ROA), NON-PERFORMING FINANCING (NPF), DAN FINANCING TO DEPOSIT RATIO (FDR) BANK PANIN DUBAI SYARIAH SEBELUM DAN SESUDAH IPO PERIODE 2011-2017

2017. Tahun 2014 merupakan tahun IPO sehingga tidak disertakan dalam perhitungan penelitian ini.

\section{Populasi dan Sampel}

Populasi pada penelitian ini adalah perbankan yang telah melakukan IPO dan terdaftar di Bursa Efek Indonesia.

Teknik pengambilan sampel yang digunakan dalam penelitian ini adalah metode purposive sampling, yaitu metode pengambilan sampel yang didasarkan pada beberapa pertimbangan dan kriteria tertentu. Pada penelitian ini kriteria sampel yang digunakan yaitu:

1. Bank Umum Syariah yang telah melakukan Initial Public Offering (IPO) dan terdaftar di Bursa Efek Indonesia (BEI).

2. Bank Umum Syariah yang telah menerbitkan laporan keuangan minimal 3 tahun sebelum dan 3 tahun sesudah IPO.

Berdasarkan batasan-batasan kriteria tersebut, maka Bank Umum Syariah yang telah memenuhi kriteria sampel yang digunakan adalah Bank Panin Dubai Syariah.

\section{Teknik Analisis Data}

Metode analisis yang digunakan untuk melakukan pengujian hipotesis penelitian ini adalah Paired TTest apabila data terdistribusi secara normal dan Wilcoxon Signed Rank Test apabila data terdistribusi secara tidak normal.

IV. HASIL DAN PEMBAHASAN

Statistik Deskriptif Capital Adequacy

Ratio (CAR)

Tabel 1.

Statistik Deskriptif Capital Adequacy Ratio (CAR) Sebelum dan Sesudah IPO

\begin{tabular}{|l|l|l|}
\hline & \multicolumn{1}{|c|}{$\begin{array}{c}\text { CAR } \\
\text { Sebelum } \\
\text { IPO }\end{array}$} & \multicolumn{1}{|c|}{$\begin{array}{c}\text { CAR } \\
\text { Sesudah } \\
\text { IPO }\end{array}$} \\
\hline$N$ & 12 & 12 \\
\hline Minimum & 19.75 & 11.51 \\
\hline Maxiumum & 100.63 & 24.71 \\
\hline Mean & 46.0067 & 18.9767 \\
\hline Std. & 25.67595 & 3.24276 \\
\hline Deviation & & \\
\hline
\end{tabular}

Sumber : Hasil Penelitian, 2018 (diolah)

Berdasarkan data pada tabel 1 menunjukkan bahwa CAR minimum Bank Panin Dubai Syariah saat sebelum IPO adalah 19,75 yang terjadi pada bulan September 2013 dan yang paling maksimum adalah 100,63 yang terjadi pada bulan Juni 2011. Sedangkan saat sesudah IPO, CAR paling minimum adalah 11,51 yang terjadi pada bulan Desember 2017 dan yang paling maksimum adalah 24,71 yang terjadi pada bulan Maret 2015. CAR Bank Panin Dubai Syariah sebelum IPO mempunyai rata-rata sebesar 46,0067, sedangkan CAR sesudah IPO memiliki rata-rata sebesar 18,9767. Standar deviasi untuk CAR Bank Panin Dubai Syariah sebelum IPO adalah 25,67595, sedangkan standar 
Sholichah, et al/Jurnal Ekonomi Syarieh Teori dan Terapan Vol. 6 No. 2 Februari 2019: 228-242; ANALISA CAPITAL ADEQUACY RATIO (CAR), RETURN ON ASSET (ROA), NON-PERFORMING FINANCING (NPF), DAN FINANCING TO DEPOSIT RATIO (FDR) BANK PANIN DUBAI SYARIAH SEBELUM DAN SESUDAH IPO PERIODE 2011-2017

deviasi CAR sesudah IPO adalah 3,24276 .

\section{Statistik Deskriptif Non-Performing Financing (NPF)}

Tabel 2.

Statistik Deskriptif Non Performing Financing (NPF) Sebelum dan Sesudah IPO

\begin{tabular}{|l|l|l|}
\hline & \multicolumn{1}{|c|}{$\begin{array}{c}\text { NPF } \\
\text { Sebelum } \\
\text { IPO }\end{array}$} & \multicolumn{1}{|c|}{$\begin{array}{c}\text { NPF } \\
\text { Sesudah } \\
\text { IPO }\end{array}$} \\
\hline $\mathrm{N}$ & 12 & 12 \\
\hline Minimum & .00 & .88 \\
\hline Maxiumum & 1.05 & 12.52 \\
\hline Mean & .5083 & 3.3142 \\
\hline $\begin{array}{l}\text { Std. } \\
\text { Deviation }\end{array}$ & .35721 & 3.07508 \\
\hline
\end{tabular}

Sumber : Hasil Penelitian, 2018 (diolah)

Data pada tabel 2 menunjukkan bahwa NPF paling minimum Bank Panin Dubai Syariah saat sebelum IPO adalah 0 yang terjadi pada bulan Maret 2011 dan yang paling maksimum adalah 1,05 yang terjadi pada bulan September 2013. Sedangkan saat sesudah IPO, NPF paling minimum adalah 0,88 yang terjadi pada bulan Maret 2015 dan yang paling maksimum adalah 12,52 yang terjadi pada bulan Desember 2017.

NPF Bank Panin Dubai Syariah sebelum IPO mempunyai rata-rata sebesar 0,5083, sedangkan NPF sesudah IPO memiliki rata-rata sebesar 3,3142. Standar deviasi untuk NPF Bank Panin Dubai Syariah sebelum IPO adalah 0,35721, sedangkan standar deviasi NPF sesudah IPO adalah 3,07508.

\section{Statistik Deskriptif Return On Asset (ROA)}

Berdasarkan data pada tabel 3 menunjukkan bahwa ROA paling minimum saat sebelum IPO adalah 1,55 yang terjadi pada bulan Maret 2011 dan yang paling maksimum adalah 3,29 yang terjadi pada bulan Desember 2012. Sedangkan saat sesudah IPO, ROA paling minimum terjadi pada bulan Desember 2017, yaitu $-10,77$ dan yang paling maksimum adalah 1,56 yang terjadi pada bulan Maret 2015.

ROA Bank Panin Dubai Syariah sebelum IPO mempunyai rata-rata sebesar 1,6625, sedangkan ROA sesudah IPO memiliki rata-rata sebesar $-0,2358$. Standar deviasi untuk ROA Bank Panin Dubai Syariah sebelum IPO adalah 1,53851, sedangkan standar deviasi ROA sesudah IPO adalah 3,34709 .

Tabel 3.

Statistik Deskriptif Return On Asset (ROA) Sebelum dan Sesudah IPO

\begin{tabular}{|l|l|l|}
\hline & \multicolumn{1}{|c|}{$\begin{array}{c}\text { ROA } \\
\text { Sebelum } \\
\text { IPO }\end{array}$} & \multicolumn{1}{|c|}{$\begin{array}{c}\text { ROA } \\
\text { Sesudah } \\
\text { IPO }\end{array}$} \\
\hline N & 12 & 12 \\
\hline Minimum & -1.55 & -10.77 \\
\hline Maxiumum & 3.29 & 1.56 \\
\hline Mean & 1.6625 & -.2358 \\
\hline Std. & 1.53851 & 3.34709 \\
\hline Deviation & & \\
\hline
\end{tabular}


Sholichah, et al/Jurnal Ekonomi Syarieh Teori dan Terapan Vol. 6 No. 2 Februari 2019: 228-242; ANALISA CAPITAL ADEQUACY RATIO (CAR), RETURN ON ASSET (ROA), NON-PERFORMING FINANCING (NPF), DAN FINANCING TO DEPOSIT RATIO (FDR) BANK PANIN DUBAI SYARIAH SEBELUM DAN SESUDAH IPO PERIODE 2011-2017

Sumber : Hasil Penelitian, 2018 (diolah)

Statistik Deskriptif Financing to Deposit Ratio (FDR)

Tabel 4.

Statistik Deskriptif Financing to Deposit Ratio (FDR) Sebelum dan Sesudah IPO

\begin{tabular}{|l|l|l|}
\hline & \multicolumn{1}{|c|}{$\begin{array}{c}\text { FDR } \\
\text { Sebelum } \\
\text { IPO }\end{array}$} & \multicolumn{1}{|c|}{$\begin{array}{c}\text { FDR } \\
\text { Sesudah } \\
\text { IPO }\end{array}$} \\
\hline N & 12 & 12 \\
\hline Minimum & 78.64 & 86.95 \\
\hline Maxiumum & 205.31 & 97.58 \\
\hline Mean & 127.8392 & 92.6800 \\
\hline Std. & 34.26549 & 3.23682 \\
\hline Deviation & & \\
\hline
\end{tabular}

Sumber : Hasil Penelitian, 2018 (diolah)

Berdasarkan data pada tabel 4 menunjukkan bahwa FDR paling minimum saat sebelum IPO adalah 78,64 yang terjadi pada bulan Maret 2011 dan yang paling maksimum adalah 205,31 yang terjadi pada bulan September 2011. Sedangkan saat sesudah IPO, FDR paling minimum adalah 86,95 yang terjadi pada bulan Desember 2017 dan yang paling maksimum adalah 97,58 yang terjadi pada bulan Juni 2015.

FDR Bank Panin Dubai Syariah sebelum IPO mempunyai rata-rata sebesar 127,8392, sedangkan FDR sesudah IPO memiliki rata-rata sebesar 92,6800. Standar deviasi untuk FDR Bank Panin Dubai Syariah sebelum IPO adalah 34,26549, sedangkan standar deviasi FDR sesudah IPO adalah 3,23682.
Uji Normalitas

Tabel 5.

Hasil Uji Normalitas One Sample Kolmogorov-Smirnov Test

\begin{tabular}{|c|c|c|}
\hline Variabel & Sig. & Hasil \\
\hline CAR & .076 & Normal \\
\hline NPF & .158 & Normal \\
\hline ROA & .026 & Tidak Normal \\
\hline FDR & .039 & Tidak Normal \\
\hline
\end{tabular}

Sumber : Hasil Penelitian, 2018 (diolah)

Hasil uji normalitas pada

CAR dan NPF menunjukkan nilai asymp. Sig (2-tailed) sebesar 0,076 dan 0,158. Kedua data tersebut menunjukkan nilai asymp. Sig (2tailed) > 0,05, maka data berdistribusi normal. Sedangkan hasil uji normalitas pada ROA dan FDR menunjukkan nilai asymp. Sig (2-tailed) sebesar 0,026 dan 0,039. Kedua data tersebut menunjukkan nilai asymp. Sig (2-tailed) $<0,05$, maka data berdistribusi tidak normal.

\section{Uji Hipotesis}

Tabel 6.

Hasil Uji Paired T-Test

\begin{tabular}{|l|l|l|}
\hline Rasio & Sig. & Keputusan \\
\hline CAR & .002 & HO diterima \\
\hline NPF & .006 & HO diterima \\
\hline
\end{tabular}

Sumber : Hasil Penelitian, 2018 (diolah) Hasil pengujian dapat dilihat melalui tabel 6. Nilai sig. (2-tailed) pada CAR yang dihasilkan adalah 0,002. Sedangkan nilai sig. (2-tailed) NPF yang dihasilkan adalah 0,006. Keduanya lebih kecil dari tingkat signifikansi $1 \%, 5 \%$, dan $10 \%$ sehingga 
Sholichah, et al/Jurnal Ekonomi Syarieh Teori dan Terapan Vol. 6 No. 2 Februari 2019: 228-242; ANALISA CAPITAL ADEQUACY RATIO (CAR), RETURN ON ASSET (ROA), NON-PERFORMING FINANCING (NPF), DAN FINANCING TO DEPOSIT RATIO (FDR) BANK PANIN DUBAI SYARIAH SEBELUM DAN SESUDAH IPO PERIODE 2011-2017

dapat disimpulkan bahwa ada perbedaan signifikan terhadap CAR dan NPF pada Bank Panin Dubai Syariah sebelum dan sesudah IPO.

Tabel 7. Hasil Uji Wilcoxon Signed Rank Test

\begin{tabular}{|l|l|l|}
\hline Rasio & Sig. & Keputusan \\
\hline CAR & .099 & H0 diterima \\
\hline NPF & .005 & H0 diterima \\
\hline
\end{tabular}

Sumber : Hasil Penelitian, 2018 (diolah)

Pada tabel 7 dapat diketahui bahwa Nilai asymp. Sig (2-tailed) ROA yang dihasilkan adalah 0,099. Nilai sig. (2-tailed) pada CAR yang dihasilkan adalah 0,002. Nilai asymp. Sig (2-tailed) FDR yang dihasilkan adalah 0,005. Keduanya lebih kecil dari tingkat signifikansi $1 \%, 5 \%$, dan $10 \%$ sehingga dapat disimpulkan bahwa ada perbedaan signifikan terhadap ROA dan FDR pada Bank Panin Dubai Syariah sebelum dan sesudah IPO.

\section{Pembahasan}

\section{Capital Adequacy Ratio (CAR) Bank} Panin Dubai Syariah Sebelum dan Sesudah IPO

Berdasarkan hasil pengujian hipotesis menunjukkan bahwa ada perbedaan signifikan pada CAR Bank Panin Dubai Syariah sebelum dan sesudah IPO. Hasil ini mendukung penelitiaan Fitriani dan Agustin (2016).

Ada perbedaan signifikan pada CAR sebelum dan sesudah IPO juga ditunjukkan bahwa CAR mengalami penurunan setelah Bank Panin Dubai Syariah melakukan IPO.
Terlihat pada tabel 1 bahwa rata-rata CAR sebelum IPO sebesar 46,00067, sedangkan rata-rata sesudah IPO sebesar 18,9767. Penurunan ini dipengaruhi oleh meningkatnya ATMR terutama ATMR kredit karena pemasukan dana dari IPO menyebabkan meningkatnya kredit sesudah IPO, namun modal bank secara umum mengalami pertumbuhan yang sangat sedikit.

Dengan adanya IPO, diharapkan kinerja keuangan Bank Panin Dubai Syariah yang diukur dengan rasio CAR mengalami peningkatan. Namun, dalam praktiknya, nilai CAR Bank Panin Dubai Syariah sesudah IPO mengalami penurunan hingga mencapai level $11,51 \%$ di tahun 2017. Penurunan tersebut dapat disebabkan karena kondisi penurunan kualitas pembiayaan pada Bank Panin Dubai Syariah yang terjadi tahun 2017 sehingga bank memerlukan tambahan beban Penyisihan Penghapusan Aktiva Produktif (PPAP) yang mengakibatkan menurunnya kategori kolektibilitas Bank Panin Dubai Syariah dari kategori 2 ke kategori 3 dan 4 sehingga menyebabkan kerugian hingga $\mathrm{Rp}$ 974,80 miliar dan berdampak pada penurunan permodalan Bank Panin Dubai Syariah. 
Sholichah, et al/Jurnal Ekonomi Syarieh Teori dan Terapan Vol. 6 No. 2 Februari 2019: 228-242; ANALISA CAPITAL ADEQUACY RATIO (CAR), RETURN ON ASSET (ROA), NON-PERFORMING FINANCING (NPF), DAN FINANCING TO DEPOSIT RATIO (FDR) BANK PANIN DUBAI SYARIAH SEBELUM DAN SESUDAH IPO PERIODE 2011-2017

Non Performing Financing (NPF) Bank Panin Dubai Syariah Sebelum dan Sesudah IPO

Berdasarkan hasil pengujian hipotesis menunjukkan bahwa ada perbedaan signifikan pada NPF Bank Panin Dubai Syariah sebelum dan sesudah IPO. Hasil ini mendukung penelitian Wetik (2013).

Ada perbedaan signifikan pada NPF sebelum dan sesudah IPO juga ditunjukkan bahwa NPF mengalami peningkatan setelah Bank Panin Dubai Syariah melakukan IPO. Terlihat pada tabel 2 bahwa rata-rata NPF sebelum IPO sebesar 0,5083, sedangkan rata-rata sesudah IPO sebesar 3,3142. Dalam hal ini, apabila bank mendapat tambahan modal setelah melakukan IPO yang kemudian dapat digunakan untuk ekspansi pembiayaan bank, maka pembiayaan bank akan mengalami kenaikan. Namun, hal tersebut juga dapat menimbulkan adanya peningkatan pada risiko pembiayaan bermasalah.

Dengan adanya IPO, diharapkan kinerja keuangan Bank Panin Dubai Syariah yang diukur dengan rasio NPF semakin rendah yang berarti bahwa kinerja tersebut semakin baik. Namun dalam praktiknya, nilai NPF Bank Panin Dubai Syariah sesudah IPO justru mengalami peningkatan.
Peningkatan yang sangat tajam terjadi pada tahun 2017. Nilai NPF pada tahun 2017 berada pada level 12,52\%. Peningkatan Peningkatan tersebut dapat disebabkan karena adanya kenaikan pembiayaan bermasalah di Bank Panin Dubai Syariah.

\section{Return On Asset (ROA) Bank Panin}

Dubai Syariah Sebelum dan Sesudah IPO

Berdasarkan hasil pengujian hipotesis menunjukkan bahwa ada perbedaan signifikan pada ROA Bank Panin Dubai Syariah sebelum dan sesudah IPO. Hasil ini mendukung penelitian Alanazi et. al. (2011).

Ada perbedaan signifikan pada ROA sebelum dan sesudah IPO juga ditunjukkan bahwa ROA mengalami penurunan setelah Bank Panin Dubai Syariah melakukan IPO. Terlihat pada tabel 3 bahwa rata-rata ROA sebelum IPO sebesar 1,6625, sedangkan rata-rata sesudah IPO sebesar $-0,2358$. Menurunnya nilai ROA dikarenakan nilai aset yang dimiliki bank mengalami kenaikan yang cukup tinggi, terutama dari aktivitas pembiayaan yang meningkat.

Dengan adanya IPO, diharapkan kinerja keuangan Bank Panin Dubai Syariah yang diukur dengan rasio ROA mengalami peningkatan. Namun dalam praktiknya, nilai ROA Bank Panin Dubai Syariah sesudah IPO justru mengalami 
Sholichah, et al/Jurnal Ekonomi Syarieh Teori dan Terapan Vol. 6 No. 2 Februari 2019: 228-242; ANALISA CAPITAL ADEQUACY RATIO (CAR), RETURN ON ASSET (ROA), NON-PERFORMING FINANCING (NPF), DAN FINANCING TO DEPOSIT RATIO (FDR) BANK PANIN DUBAI SYARIAH SEBELUM DAN SESUDAH IPO PERIODE 2011-2017

penurunan yang sangat tajam pada tahun 2017 hingga mencapai level $10,77 \%$. Penurunan ini disebabkan karena Bank Panin Dubai Syariah mengalami kerugian hingga mencapai angka -Rp 974.802.712.000,pada tahun 2017. Di samping itu, penurunan ROA ini mengindikasikan bahwa bank kurang dapat mengoptimalkan aset yang dimilikinya sehingga pada tahun 2017 Bank Panin Dubai Syariah mengalami kerugian.

Financing to Deposit Ratio (FDR) Bank Panin Dubai Syariah Sebelum dan Sesudah IPO

Financing to Deposit Ratio (FDR) merupakan salah satu indikator rasio likuiditas bank syariah yang digunakan untuk mengukur kemampuan bank dalam memenuhi kewajiban hutanghutangnya, dapat membayar kembali semua deposannya serta memenuhi permintaan kredit yang diajukan dengan tepat waktu.

Berdasarkan hasil pengujian hipotesis yang terlihat dalam tabel 4.12 menunjukkan bahwa ada perbedaan signifikan pada FDR Bank Panin Dubai Syariah sebelum dan sesudah IPO. Hasil ini mendukung penelitian Wetik (2013). Ada perbedaan signifikan pada FDR sebelum dan sesudah IPO juga ditunjukkan bahwa FDR mengalami penurunan setelah Bank Panin Dubai Syariah melakukan IPO. Terlihat pada tabel 4 bahwa rata-rata
FDR sebelum IPO sebesar 127,8392, sedangkan rata-rata sesudah IPO sebesar 92,6800. Penurunan nilai FDR menunjukkan bahwa sesudah IPO, bank hanya terfokus untuk mengelola dana tambahan yang diperoleh melalui IPO, salah satunya untuk ekspansi pembiayaan. Sehingga jumlah Dana Pihak Ketiga semakin besar dan berdampak terhadap penurunan nilai FDR. Dengan adanya IPO, diharapkan kinerja keuangan Bank Panin Dubai Syariah yang diukur dengan rasio FDR berada dalam batas yang telah ditentukan BI. Namun dalam praktiknya, nilai FDR Bank Panin Dubai Syariah sesudah IPO justru semakin mengalami penurunan hingga berada pada level 86,95 tahun 2017. Penurunan ini dapat disebabkan oleh kurangnya efektivitas bank dalam menyalurkan pembiayaan sehingga jumlah DPK mengalami peningkatan.

\section{v. SIMPULAN}

Berdasarkan analisis data dan pembahasan pada bab sebelumnya, dalam penelitian ini dapat diambil kesimpulan sebagai berikut:

1. Rasio permodalan yang dihitung dengan menggunakan Capital $\begin{array}{lrr}\text { Adequacy } & \text { Ratio } & \text { (CAR) } \\ \text { menunjukkan } & \text { bahwa } & \text { ada } \\ \text { perbedaan signifikan } & \text { CAR } \\ \text { sebelum dan sesudah Initial Public } \\ \text { Offering, namun perbedaan } \\ \text { tersebut menunjukkan bahwa }\end{array}$ 
Sholichah, et al/Jurnal Ekonomi Syarieh Teori dan Terapan Vol. 6 No. 2 Februari 2019: 228-242;

ANALISA CAPITAL ADEQUACY RATIO (CAR), RETURN ON ASSET (ROA), NON-PERFORMING FINANCING (NPF), DAN FINANCING TO DEPOSIT RATIO (FDR) BANK PANIN DUBAI SYARIAH SEBELUM DAN SESUDAH IPO PERIODE 2011-2017

kinerja CAR Bank Panin Dubai Syariah sebelum Initial Public Offering tidak lebih baik dibandingkan dengan sesudah Initial Public Offering.

2. Rasio Kualitas Aktiva Produktif (KAP) yang dihitung dengan menggunakan Non Performing Financing (NPF), menunjukkan bahwa ada perbedaan signifikan NPF sebelum dan sesudah Initial Public Offering, namun perbedaan tersebut menunjukkan bahwa kinerja NPF Bank Panin Dubai Syariah sebelum Initial Public Offering tidak lebih baik dibandingkan dengan sesudah Initial Public Offering.

3. Rasio rentabilitas yang dihitung dengan menggunakan Return on Asset (ROA), menunjukkan bahwa ada perbedaan signifikan ROA sebelum dan sesudah Initial Public Offering, namun perbedaan tersebut menunjukkan bahwa kinerja ROA Bank Panin Dubai Syariah sebelum Initial Public Offering tidak lebih baik dibandingkan dengan sesudah Initial Public Offering.

4. Rasio likuiditas yang dihitung dengan menggunakan Financing to Deposit Ratio (FDR), menunjukkan bahwa ada perbedaan signifikan FDR sebelum dan sesudah Initial Public Offering namun perbedaan tersebut menunjukkan bahwa kinerja FDR Bank Panin Dubai Syariah sebelum Initial Public Offering tidak lebih baik dibandingkan dengan sesudah Initial Public Offering.

Saran yang dapat direkomendasikan terkait dengan penelitian ini adalah sebagai berikut:

1. Untuk manajemen Bank Panin Dubai Syariah agar lebih optimal dalam memanfaatkan tambahan modal yang diperoleh melalui IPO. Bank Panin Dubai Syariah juga perlu lebih cermat dan lebih selektif dalam menganalisis kriteria calon nasabah yang akan diberikan pembiayaan, baik analisis kualitatif maupun analisis kuantitatif sehingga jumlah pembiayaan bermasalah berkurang. Minimnya jumlah pembiayaan bermasalah di bank akan berpengaruh terhadap peningkatan laba perusahaan dan kinerja perusahaan.

2. Untuk investor, sebaiknya tidak tergesa-gesa dalam mengambil keputusan. Meskipun kinerja Bank Panin Dubai Syariah mengalami penurunan yang sangat tajam pada tahun 2017, namun Bank Panin Dubai Syariah masih memiliki potensi untuk terus tumbuh mengingat Dubai Islamic Bank dan Bank Panin masih terus 
Sholichah, et al/Jurnal Ekonomi Syarieh Teori dan Terapan Vol. 6 No. 2 Februari 2019: 228-242;

ANALISA CAPITAL ADEQUACY RATIO (CAR), RETURN ON ASSET (ROA), NON-PERFORMING FINANCING (NPF), DAN FINANCING TO DEPOSIT RATIO (FDR) BANK PANIN DUBAI SYARIAH SEBELUM DAN SESUDAH IPO PERIODE 2011-2017

mendorong pertumbuhan bank dengan memberikan setoran modal. Dengan melakukan investasi saham Bank Panin Dubai Syariah, investor secara tidak langsung juga ikut mendorong pertumbuhan bank syariah di Indonesia.

3. Untuk penelitian selanjutnya agar menambahkan penggunaan variabel penelitian serta menggunakan periode penelitian yang lebih lama, semisal 5 tahun sebelum dan sesudah IPO. Banyaknya variabel penelitian dan periode penelitian yang digunakan dalam menganalisis kinerja kevangan perbankan sebelum dan sesudah IPO, diharapkan dapat memberikan hasil penelitian yang lebih optimal.

\section{DAFTAR PUSTAKA}

Abdillah, Willy dan Jogiyanto Hartono M. 2015. Partial Least Square (PLS). Yogyakarta: Penerbit Andi.

Alanazi, Ahmed S. and Benjamin Liu. 2013. IPO Financial and Operating Performance: Evidence from the Six Countries of the GCC, (Online), (https://www.researchgate.net diakses tanggal 12 Januari 2018).

Ansori, Muslich dan Sri Iswati. 2009. Metodologi Penelitian
Kuantitatif. Surabaya: Airlangga University Press.

Az-Zuhaili, Wahbah. 2013. Tafsir Al-Munir jilid 2 (Juz 3-4). Penerjemah: Abdul Hayyie al-Kattani, dkk. Jakarta: Gema Insani.

Bank Indonesia. 2013. Pedoman Akuntansi Perbankan Syariah Indonesia.

Bank Panin Dubai Syariah. Laporan Keuangan Triwulan Bank Panin Dubai Syariah Bulan Maret 2011 - Desember 2017, (Online). (www.paninbanksyariah.co.id, diakses tanggal 1 Desember 2017).

Danupranata, Gita. 2013. Manajemen Perbankan Syariah. Jakarta: Salemba Empat.

Dendawijaya, Lukman. 2009. Manajemen Perbankan. Jakarta: Ghalia Indonesia.

Departemen Agama Republik Indonesia. 2002. Al Quran dan Terjemahannya. Jakarta: Departemen Agama Republik Indonesia

Fitriani, Riska Nurul dan Sasi Agustin. 2016. Analisis Kinerja Keuangan Sebelum dan Sesudah Go Public. Jurnal IImu dan Riset Manajemen, (Online), Vol. 5, No.

(https://ejournal.stiesia.ac.id/ diakses tanggal 12 Februari 2018). 
Sholichah, et al/Jurnal Ekonomi Syarieh Teori dan Terapan Vol. 6 No. 2 Februari 2019: 228-242;

ANALISA CAPITAL ADEQUACY RATIO (CAR), RETURN ON ASSET (ROA), NON-PERFORMING FINANCING (NPF), DAN FINANCING TO DEPOSIT RATIO (FDR) BANK PANIN DUBAI SYARIAH SEBELUM DAN SESUDAH IPO PERIODE 2011-2017

Ghozali, Imam. 2013. Aplikasi Analisis Multivariate Dengan Program IBM SPSS 21. Semarang: Badan Penerbit Universitas Diponegoro.

Hutagalung, Esther Novelina, Djumahir, dan Kusuma Ratnawati. 2013. Analisa Rasio Keuangan terhadap Kinerja Bank Umum di Indonesia, Jurnal Aplikasi dan Manajemen, (Online), (http://jurnaljam.ub.ac.id/ diakses tanggal 1 Maret 2018).

Ikatan Bankir Indonesia. 2014. Memahami Bisnis Bank Syariah. Jakarta: PT Gramedia Pustaka Utama.

Kasmir. 2016. Analisis Laporan Kevangan. Jakarta: Raja Grafindo Persada.

Kuncoro dan Suhardjono. 2002. Manajemen Perbankan: Teori dan Aplikasi. Yogyakarta: BPFE.

Mardani. 2015. Aspek Hukum Lembaga Kevangan Syariah di Indonesia. Jakarta: Kencana Prenadamedia Group.

Muhamad. 2015. Manajemen Dana Bank Syariah. Jakarta: Raja Grafindo Persada.

Munisi, Gibson Hosea. 2017. Financial Performance of Initial Public Offerings: Companies Listed on Dar es Salaam Stock Exchange. Business and Economics Journal, (Online), Vol. 8, (http://astonjournals.com/ diakses tanggal 12 Januari 2018).

Peraturan Bank Indonesia Nomor 15/12/PBI/2013 Tentang Kewajiban Penyediaan Modal Minimum Bank.

Peraturan Bank Indonesia Nomor 3/25/PBI/2001 Tentang Penetapan Status Bank dan Penyerahan Bank Kepada Badan Penyehatan Perbankan Nasional.

Quthb, Sayyid. 2001. Tafsir Fi Zhilalil Qur'an di Bawah Naungan AlQur'an Jilid 4. Jakarta: Gema Insani Press.

Surat Edaran Bank Indonesia Nomor 13/24/DPNP Tanggal 25 Oktober 2011.

Surat Edaran Bank Indonesia Nomor 3/30/DPNP Tanggal 14 Desember 2001.

Sutedi, Adrian. 2011. Pasar Modal Syariah. Jakarta: Sinar Grafika. Tandelilin, Eduardus. 2010. Portofolio dan Investasi. Edisi Pertama. Yogyakarta: Kanisius.

Umam, Khaerul. 2013. Manajemen Perbankan Syariah. Bandung: Pustaka Setia.

Undang-undang Republik Indonesia Nomor 21. 2008. "Undangundang Republik Indonesia Nomor 21 Tahun 2008 tentang Perbankan Syariah" 
Sholichah, et al/Jurnal Ekonomi Syarieh Teori dan Terapan Vol. 6 No. 2 Februari 2019: 228-242;

ANALISA CAPITAL ADEQUACY RATIO (CAR), RETURN ON ASSET (ROA), NON-PERFORMING FINANCING (NPF), DAN FINANCING TO DEPOSIT RATIO (FDR) BANK PANIN DUBAI SYARIAH SEBELUM DAN SESUDAH IPO PERIODE 2011-2017

Undang-undang Republik Indonesia

Nomor 8. 1995. "Undang-

undang Republik Indonesia

Nomor 8 Tahun 1995 tentang

Pasar Modal"

Wetik, Wilhelm A.A. 2013. Analysis of Financial Performance Pre and Post Initial Public Offering (IPO) at Bank Central Asia Tbk. Jurnal EMBA, (Online), Vol. 1, No. 4, (http://download.portalgaruda. org/article.php? article $=109064$ \&val=1025, diakses tanggal 11 Januari 2018).

Widjaja, Gunawan dan Wulandari Risnamanitis, D. 2009. Seri Pengetahuan Pasar Modal: Go Public dan Go Private di Indonesia. Jakarta: Kencana Prenada Media Group.

Wirajunayasa, Putu Agus Agung dan I.G.A.M. Asri Dwija Putri. 2010. Analisis Kinerja Keuangan Perusahaan Sebelum dan Sesudah Initial Public Offering. Jurnal Akuntansi Universitas Udayana, (Online), Vol. 19, (https://ojs.unud.ac.id/index.ph p/Akuntansi/article/view/24408, diakses pada 28 Mei 2018). 